Borshch V. I., PhD in Economics, Associate Professor of Management and Innovations Department, Odessa national I. I. Mechnikov University, Ukraine

ORCID ID: 0000-0001-9106-9078

e-mail: viktoriyaborshch@gmail.com

Aizenshtat A. L., BA in Management, MA student in Management of the Foreign Economic Activity, Odessa national I. I. Mechnikov University, Ukraine

e-mail: aizenshtat1995@gmail.com

\title{
Collaborative Approach to Management Using a Three-Way Management Model
}

Abstract. Due to the current economic instability, environmental and social change the problem of collaborative governance is very urgent for Ukraine, as well as other developing countries. The purpose of this scientific article is to examine theoretical and practical applications of the collaborative approach to the governing of the state, using a tripartite management model. In particular, the paper investigates the tripartite model (triad) as an integrative framework that includes three sectorssocial, political and financial. The political sector is represented in government, financial one in for-profit organizations, and social sector in any chosen NGO or NPO, which will act as a mediator between the public and government. Moreover, the author suggests that only though collaboration between those three sectors the effectiveness of the state governance could be achieved, also ensuring the sustainable development. The article presents a compelling argument against establishing sole power in the hands of a single institutional entity, instead outlining the possible benefits of sharing power and responsibility among all citizens. Using the example of Ukraine, it delineates a potential scenario where state adopts the triad to undertake a path to sustainable development. Therefore, while the article limitations might be in that it carries mostly theoretical implication of the tripartite management model, it nevertheless builds a successful ground for adoption of this model in the future by any developing country.

Keywords: collaborative governance; corporate social responsibility; Ukraine; non-profit organization; nongovernmental organization.

\section{Удк 330}

Борщ В. I., кандидат економічних наук, доцент кафедри менеджменту та інновацій, Одеський національний університет імені I. І. Мечникова

Айзенштат А. Л., бакалавр менеджменту, студент магістерської програми Менеджмент зовнішньоекономічної діяльності, Одеський національний університет імені I. І. Мечникова

\section{Колаборативний підхід до управління з використанням тристоронньої моделі менеджменту}

Анотація. Через економічну нестабільність, екологічні та соціальні зміни проблема колаборативного управління є надзвичайно актуальною як для України, так і для інших країн, що розвиваються. Метою цієї статті $\epsilon$ обгрунтування теоретичних положень та особливостей практичного застосування колаборативного підходу до управління державою з використанням тристоронньої моделі управління. Досліджено тристоронню модель (тріаду) як інтегративну структуру, яка містить три сектори: соціальний, політичний та фінансовий. Політичний сектор представлений в уряді, фінансовий - у комерційних організаціях, а соціальний - у будь-яких недержавних організаціях, які виступають посередниками між громадськістю та урядом. Крім того, автори припускають, що лише завдяки співпраці між цими трьома секторами може бути досягнута ефективність управління державою, що також може забезпечити сталий розвиток. У статті викладено переконливий аргумент проти встановлення єдиної влади в руках одного інституційного утворення, натомість окреслено можливі переваги розподілу влади та відповідальності між усіма громадянами. На прикладі Украӥни окреслюється потенційний сценарій, коли держава приймає тріаду задля проходження шляху до сталого розвитку. Хоча обмеження статті і можуть полягати в тому, що в основному увага приділена теоретичному обгрунтуванню тристоронньої моделі управління, проте саме воно створює успішний грунт для практичного застосування цієї моделі в майбутньому.

Ключові слова: колаборативне управління; корпоративна соціальна відповідальність; Україна; неприбуткова організація; неурядова організація.

Problem statement. At the time when we are facing uncertain future, due to the current economic instability, environmental and social change, the era of selfregulating economies and renewable outlook towards nature has approached its limitations and became obsolete. While Smith's invisible hand might still regulate the market, with current population growth rates, idea of abandoning heavy government regulations no longer stands. At this juncture, it is worth looking at possible additional measures that would help governments of 
developed economies, but more so to the developing counties to arrive at the right decisions for the state. The decision that would incorporate different perspectives and encompass all possible sectors involved, forming a harmonious governing structure. The aforementioned sectors will form a tripartite management model, consisting of social, political and financial parts. Such comprehensive model offers addressing any issues from those three angles, thereby guaranteeing the maximization of impartiality and social welfare.

Analysis of recent research and publications. The problem of collaborative governance war researched by the following authors, as John M. Keynes [1], Howard W. Eimicke and William B. Buffett [3], Sverige Sweden [4], James E. Austin and May M. Seianidi [5], Geri Stengel [6] and so on.

Formulation of research goals. The purpose of this scientific article is to examine theoretical and practical applications of the collaborative approach to the governing of the state, using a tripartite management model. In particular, it investigates the tripartite model (triad) as an integrative framework that includes three sectors- social, political and financial.

Presentation of the main research results. The concept of the triad is fairly simple. Primarily, it is a codependent model, which only operates in symbiosis. The value of such collaboration is much greater than what one of them can accomplish on their own, which is due to the current demand for the uniting of powers, taking what each of the three sectors represents. Due to its cyclicality it is worth looking at them in particular order, initial being social, followed by political and then financial. The social side is represented in an independent organization, such as NGO's that are formed by the civil society or NPO's.
Political is in government. Finally, the financial is in any for-profit organizations. Further, in this model social and political aim to achieve the three subsequent goals: determination and assessment of the concerning issues through independent research; creation of the relevant laws, policies and regulations; ensuring their implementation.

The drive for profit in financial component of the tripartite would allow for necessary funding, safeguarding the desirable socio-political outcome and corresponding progress, which is aligned with the core values of the chosen non-profit.

The social sector is bound to have the broadest spectra of responsibilities, as its role (usefulness) is not limited by the constrains of its primary communal purpose. While the NGO's would conduct research and monitor implementation, it will also function as the connecting link between the public and government, the link necessary for democratic governance. Addressing the problem of oligarchy and hierarchy in business, the social sector could remove the sole power that is concentrated in the hands of a few from the upper political echelons, bestowing it upon the masses. Public involvement will play a key role in the development of the country as it has the ability to become more orientated towards the needs of its citizens. Establishing institutions that would place greater power in the hands of the public, inevitably leads to greater social responsibility. Besides the obvious benefits of being tailored to the needs of the particular country, public responsibly would contribute greatly to countries wellbeing, as it let more people into decision making process, therefore making more reluctant to go against their own decisions.

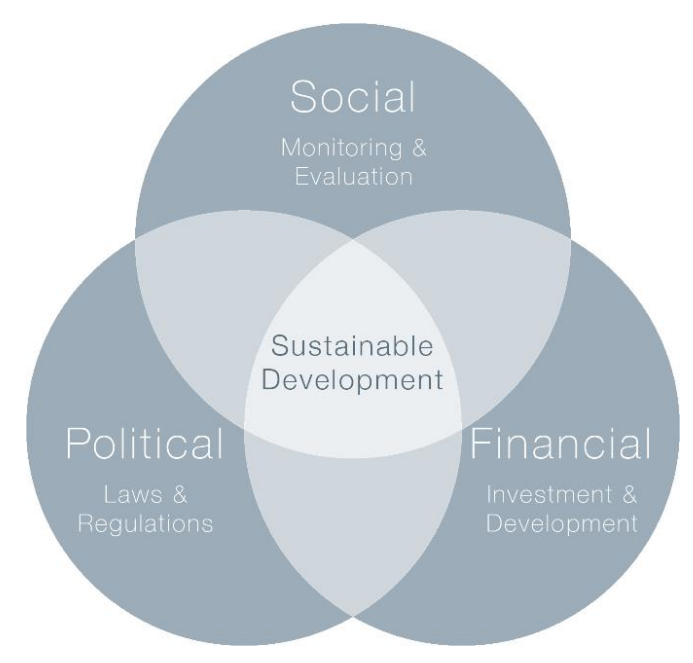

Figure 1 - Tripartite Management Model

Source: composed by authors

As a contractor to the government, the organization would have to answer both to people and the government, arguably performing the pivotal function in the model. Prioritizing the elimination of any personal gain would most likely contribute to a more successful enforcement of the goals set before the organization. Being merely an arbitrator with no monetary interest, it could have much greater support and trust from the public. By increasing the social support and interest, it would stimulate the involvement of the public in the 
issues of the state. Although a conventional wisdom says that it is harsher sentences and punishments that ensure the enforcement of the law, however it does not give the essential push for initiative of personal involvement. The initiative that often sprung from realization of the necessity to go beyond just following the laws, into being a proactive and responsible citizen. While the laws of the previous century have proven to be successful in diminishing crime, it failed completely at creating socially and environmentally safe future for the generations to come.

During the time of desperate need for social change and constant thriving for global development, the youth is now, more than ever, likely to turn to alternatives that are socially responsible. The recent global movements have proved to have a vast effect on the consciousness of the society. Many Ukrainians today are becoming more proactive both politically and socially. According to the $\mathrm{H}$. Buffet and W. Eimicke from Columbia University the majority of the millennials today, unlike the previous generations, value the making a positive difference in the world over the professional recognition. Furthermore, after conducting a survey, Bentley University research team found out that millennial generation today, is far more concerned with the social value that their job has, than any of the previous generations.

Because in the next decade millennials are going to take up the largest proportion of the global workforce, it would be only logical to have policies and businesses oriented towards their mentality. The laws today, are often referred to as outdated, which is partly attributed to the technological advancement, but mostly due to the great shift in mentality that formed in face of many social and environmental threats. During the time of fleeting tendencies, the government is expected to align.

The partnership between governmental organization and NGO's would prove to have even stronger effect, when both are oriented towards the public good. While in Ukraine, there has been rising social distrust towards politicians, NGO's are likely to take some of the pressure from governments, and make the government responsibility-a social responsibility. Make the process more transparent and accessible. The implications of such transition of power, are likely to lower the unrealistic expectations of people for the governmental role and account for greater productivity and functioning.

The trusted entity that does not profit from any of the decisions, such as NGO, is more likely to gain support from the public. Monitoring and providing the information on the current affairs might prove to be essential. Even today, fair tendering system like ProZorro, that emerged out of the collaborative governance, provide the key function, as it decreases the risk for fund manipulations and corruption, allowing for transparency and security. The ability to track all government spending, could not only reduce the current tendency of avoiding taxes, but eliminate the complete public opaqueness that is involved in the process today.
In this model, everyone makes a contribution to the wellbeing of the society. Making people more involved would likely to create a healthier environment in the society, where NGO's would be a safe space for citizens to express their desires and concerns, and therefore when certain issue has proven to have a substantial value it could then be addressed by the government. The assessment of such concerns would fall on the NGO, working as a medium between people and government. An intermediary third party represented in the social sector of the triad, and controlled by both, government and society.

The collaboration between the three sectors reflects a successful relationship between the social, organizational and monetary aspects. As noted above, the newest generation, will inevitably make choices that would be more environmentally and socially responsible. Because the environmental threat is something that they will face in their lifetime it is hard to underestimate the efforts that they will take to prevent that from happening. As we enter Anthropocene, in order to maintain a successful development in any field, it will be necessary to look beyond allocation of the existing exhaustible resources, but to address their scarcity as well as look to involve the renewable energy. The importance of the social aspect is often overlooked, but after all, further development of a particular field primarily depends on public support.

Today, sustainable development is incorporated in many of the current business models. The success of the company no longer lies in complying with principles of capitalistic model, where the best product wins the market. In both developing and developed countries, many customers are now turning to the idea that the company should bring positive social and environmental change, while many companies today still do the opposite. The research only confirms the fact that in the world of tomorrow the values will shift, the responsibility will lie on those who produce and provide the products to the society. While many firms are likely to oppose heavy government regulations, we should assume that the tripartite model would cushion the process and possibly even guarantee more mild injection of the new policies into the country.

If for-profit organization would like to be as profitable as they are now, they too, would need to adapt to the new conditions of the millennia. This does not only relate to creating the acceptable working conditions, but just as much to creating a workplace with social purpose. Both consumers and industry workers are more inclined to give their preference to the products that have a certain social value or cause, in other word companies with corporate social responsibility (CSR). The research suggests that "on the investor side, more and more shareholders demand tracking and reporting of both positive and negative externalities, compelling some of the largest corporations on earth into action". The cooperation between nonprofit and for profit are likely to eliminate such thorough interest in externalities, as it would be embodied in the 
corporate policy and guaranteed by the intervention of the social sector.

The economic effectiveness of such collaboration, is anticipated due to the engagement of the for-profit organization, as it would allow the third party to invest and have a monetary interest in the success of the collaboration. While the government and social components should have no interest in returns, the forprofit must seek the personal gain in the process in order to maximize efficiency of the whole project. In this case, the capitalistic striving towards maximizing its profit and minimizing cost, in a competitive market, is the best guarantee for the efficiency of the model.

Efficiency today is a necessary milestone for the sustainable future, that unfortunately doesn't sound appealing to most of the corporate world. What might seem expensive and unattainable today, might well be the right choice for the successful future development. To make the investment in the socially responsible businesses attractive, it is government's place to create the favorable business environment as well as the conditions for the perfect completion. Having said that, there might be many other complications along the way that are due to inability to sustain the technological advances. Both government and financial sectors are vital to the successful management model; as current technological trends require large-scale investments in all factors of production.

Although the doctrine of the laissez-faire has been gaining popularity among advanced economies in the recent decades, the idea of abandoning the government economic intervention for good is still deemed absurd. Keynesian school of thought seems to have relevance and positive influence in terms of creating fiscal policy that would adequately serve the counties best interest. On these grounds, the role of the government in the tripartite model should not be limited to tailoring certain laws and policies to the current trend but should also create a desirable environment, with financial benefits for the organizations that are willing to work for the public good, and the commensurate tariffs and regulations for those contributing to the worsening of the social and environmental cause. Tax breaks, reliefs and subsidies are many of the measures that could be taken towards creating a better environment for the socially conscious business. There could be many other financial incentives for those who are willing to work both, for and with, the government and social organizations, as partners or their employees. This practice would allow for more people to willingly go into the filed, and invest their capital and labor in development that would later allow the sustainable solutions and outcomes for the whole country.

As an illustration, reference may be made to the potential scenario where Ukraine undertakes the task of becoming self-sustainable. Before anything else, producing renewable energy, would provide a good portion of Ukraine with clean energy that does not require going into scares resources of the country. Such practice is already widely used in many of the European countries. The United Nations report states that industry accounts for over 20 percent of Ukraine's GDP. The economic recession has been affecting the volume of industrial production but has had a positive effect on the environment, since it has helped reduce GHG emissions. Such transition would allow for sustainable economic growth, widening the energy sector in Ukraine, without damaging the economy. The further expansion and investment might open new possibilities for growth in technological and agricultural sectors.

By sharing the new technology and methods, we open new opportunities and possibilities for our country to contribute and work with other developed nations, perhaps even become economically worthy member. On a grander scale this transition might affect the rural life of all Ukrainians, as today, many villages are lacking basic amenities such as sewage or water. The investment in this area will inevitably bring technological progress that would widen the use of renewable sources, reducing the future cost for all amenities, and therefore allowing to spend these funds for other needs of the society.

There has been a growing concern, among the world, regarding climate change and rising pollution. The aforementioned is often associated with mass destruction of wildlife and natural resources, which is due to the increased consumption and lack of alternative solutions. If we take a separate example of governmental collaboration with nonprofit in the field of protection of the environment we would find no adequate measures taken for creation of the sustainable infrastructure. Ukraine today is among top countries that lack proper policies, along with poor enforcement of the existing ones it could well be the fundament of increasing problem concerning environment.

According to the new Ukrainian law that entered into force on January 1st 2018, all waste has to be recycled, and sorted into the appropriate categories. Nevertheless, the government does not provide the proper funding and resources to make this possible for Ukrainians to accomplish. Although there are many public initiatives that are voluntary and funded only by the fundraising and social initiatives, they still outnumber governmental efforts. The nonprofit should become a thread that, so to say, connects the public efforts and ideas, with financial and authoritative resources, that would allow not only to create appropriate laws and enforce them but also initiate the public efforts to comply.

Applying a tripartite model approach to this task would allow for collaborative approach, ensuring the future of a sustainable development. The primary objective would be to collect data that would represent the unbiased picture demonstrating environmental landscape of Ukraine. The independent organization, that is represented the social sector of the triad, would conduct all of the initial and subsequent research, as well as monitoring and evaluation of the compliance with and implementation of the new laws. In this particular case the 
role of government is encompassed in creation of the laws and regulations, that have been based on the information gathered by the NGOs. Besides the obvious need for all for-profits to comply with the law, many of the targets set by the government for the sustainable development could not be accomplished without the help of for-profit organizations. As previously stated, the government must also create financial incentives for businesses that are environmentally responsible, which would stimulate the needed investment. Such measures would encourage the desire for development of the sustainable economy.

Considering that sustainable development is one of the conditions of the European Union for joining, to get any monetary support from the EU and other powerful countries or institutions, it is essential that we provide evidence for being able to maintain and uphold the EU standards. The limitless opportunities that arise with the increase of recycling and using the renewable energy are indisputable. Getting any foreign monetary injection into the Ukrainian economy will become considerably simpler once the country operates to ensure the stability, and reduces the negative environmental imprint that Ukraine has on the world.

To compare, Sweden has done an extensive amount of work reducing its use of non-renewable resources and is on the path of reducing its carbon footprint to a possible minimum. The governmental aim for Sweden is to use $100 \%$ renewable energy by 2040 , and it has already reached its goal for 2018, making the prediction a realistic endeavour. Today $54 \%$ of the energy comes from the renewable source. This makes it possible for a country to sustain itself without digging into the scarce resources of the country and planet, and rely on themselves, rather than on other countries to provide and potentially dictate their conditions for import.

Renewable energy is one of the key aspects of the economic growth. The stabilization of the economy lies in the ability to sustain itself, also opening a possibility for development of the other aspects of economy. By producing change in only one sector, it creates a domino effect, that sets the chain reaction that could be observed in all other sectors. As the largest country in Europe our contribution, negative or positive, is undebatable. The economic outcome of collaboration solidifies the possibility for future economic growth. By creating new jobs in this sector, it will also address one of the highest unemployment levels in Europe and, possibly, reduce the labour migration.

Conclusions. The unrealized potential of Ukraine, often referred to as the breadbasket of Europe, primarily lies in its vast fertile lands suited for agriculture. The usage of green energy would only stimulate the growth and allow Ukraine to become among the primary suppliers of agricultural products to all European members and beyond, ensuring stable economic growth, boosting net exports, therefore increasing the GDP of the country. Today it's impossible to imagine Ukraine going through this path without an external help, but in order to gain that there we must put in place the integrated approach. Triad is the approach that does not only seek for the possibility of stable and sustainable growth, but is directed to influence choices and decisions to be oriented towards creating a positive impact on the planet and the future generations.

If executed in an appropriate manner, the said collaboration reflects the harmonious relationship of every aspect that makes up a state. The tripartite model looks to create a system, that would allow to share both responsibilities and benefits with all its subjects, working together to bring the future well-being of the society and the country. Any movement towards creating the environment for the sustainable development will have an external effect, both globally influencing the planet and on every developing nation individually.

\section{References:}

1. Keynes, J. M. (1926). The end of Laissez-Faire. London: L.\& Virginia Wolf, Print.

2. United Nations (2017). National Baseline Report. Sustainable Development Goals: Ukraine.

3. Eimicke, Howard W. \& Buffett, William B. (2018). How Companies, Governments, and Nonprofits Can Create Social Change Together. Harvard Business Review, 31 May, 132-145.

4. Sweden, Sverige (2019). Energy Use in Sweden. Sweden.se. Sep. URL: https://sweden.se/society/energy-use-in-sweden/.

5. Austin, James E. \& Seianidi, May M. (2012). Collaborative Value Creation: A Review of Partnering Between Nonprofits and Businesses. Nonprofit and Voluntary Sector Quarterly, July, 56-68.

6. Stengel, Geri (2013). Nonprofit Collaborations: Why Teaming Up Can Make Sense. Forbes Magazine. URL: www.forbes.com/sites/geristengel/2013/04/09/nonprofit-collaborations-why-teaming-up-can-makesense/\#1a003e0f3985.

7. Smith, Adam (1759). The Theory of Moral Sentiments. London: Printed for A. Millar, and A. Kincaid and J. Bell.

8. Conditions for Membership (2016). European Neighborhood Policy And Enlargement Negotiations - European Commission. 6 Dec. URL: ec.europa.eu/neighbourhood-enlargement/policy/conditions-membership_en.

9. Ukraine GDP (2019). Data, World Bank Group. URL: data.worldbank.org/country/ukraine.

10. Friedman, M. \& Heller, W. (1969). Monetary vs. Fiscal Policy. W. W. Norton \& Company. April Print. 